\title{
Analysis of factors related to granting sickness benefits to industry workers on leave due to Work-related Musculoskeletal Disorders (WMSD)
}

Análise dos fatores relacionados à concessão de auxílio-doença a trabalhadores da indústria afastados por Distúrbios Osteomusculares Relacionados ao Trabalho (DORT)

Análisis de factores relacionados con la concesión de auxilio-enfermedad a trabajadores en baja por Trastornos Musculoesqueléticos del Trabajo (TMERT)

\begin{abstract}
Background: Sickness absence represents a serious problem for industry and Social Security, since many of these workers become beneficiaries by the National Social Security Institute. The relationship between the factors that lead to dismissal and granting benefits to workers in the industry has yet to be studied. Objective: To determine the relationship between social and occupational factors to granting sickness benefits to industrial workers affected by Work-related Musculoskeletal Disorders. Methods: This is a retrospective cross-sectional with quantitative approach study involving industrial workers. The data contained in the evaluation form of workers who were admitted between 2016 and 2020 in a Reference Centers in Occupational Health were used. The data were descriptively evaluated and a logistic regression model was used to estimate the factors which are related to the type of assistance granted to the workers. Results: 108 medical records of industry workers were evaluated and $56.5 \%$ received the accident-related sickness assistance benefit (B-91). Most are workers from industry with light demand (95.4\%), who perform repetitive work $(93.5 \%)$, intense work pace $(83.3 \%)$, with the shoulder being the region most frequently affected $(85.2 \%)$. The factors that were significantly related to grating accidental-related sickness benefit: time in the current occupation $(\mathrm{OR}=1.01)$, work involving cervical spine flexion $(\mathrm{OR}=4.68)$, participation in the rehabilitation program $(\mathrm{OR}=31.27)$ and referral to specialist consultations $(\mathrm{OR}=3.10)$. Conclusion: The creation of institutional programs in the industry and the implementation of public health and social security policies are necessary to manage these factors.
\end{abstract}

Keywords: Musculoskeletal diseases; Occupational health; Social security.

\section{Resumo}

Introdução: O absenteísmo por adoecimento representa um grave problema para a indústria e Previdência Social, pois muitos trabalhadores afastados se tornam beneficiários do Instituto Nacional de Seguro Social. A relação entre os fatores que levam ao afastamento e a concessão de benefícios a trabalhadores da indústria precisa ser estudada. Objetivo: Determinar a relação entre fatores sociais e ocupacionais na concessão de auxílio-doença a trabalhadores da indústria com Distúrbios Osteomusculares Relacionados ao Trabalho. Métodos: Trata-se de um estudo retrospectivo transversal com abordagem quantitativa, envolvendo trabalhadores da indústria. Foram usados os dados da ficha de 
avaliação dos trabalhadores admitidos entre 2016 e 2020 em um Centro de Referência em Saúde do Trabalhador. Foi conduzida análise descritiva e utilizada regressão logística para estimar os fatores que se relacionam ao tipo de auxilio concedido ao trabalhador. Resultados: 108 prontuários de trabalhadores da indústria foram avaliados e 56,5\% receberam o auxílio doença acidentário (B-91). A maior parte são trabalhadoras $(72,2 \%)$ de indústria com demanda leve de trabalho $(95,4 \%)$, que executam trabalho repetitivo $(93,5 \%)$, ritmo intenso de trabalho $(83,3 \%)$, sendo o ombro o segmento mais frequentemente acometido $(85,2 \%)$. Os fatores que foram significativamente relacionados à concessão de auxílio-doença acidentário: tempo na ocupação atual $(\mathrm{OR}=1.01)$, trabalho com flexão da coluna cervical $(\mathrm{OR}=4.68)$, participação no programa de reabilitação $(\mathrm{OR}=31.27)$ e encaminhamento para interconsulta com especialistas $(\mathrm{OR}=3.10)$. Conclusão: É necessária a criação de programas institucionais na indústria e a implementação de políticas públicas de saúde e de previdência social para controlar tais fatores.

Palavras-chave: Doenças musculoesqueléticas; Saúde do trabalhador; Previdência social.

\section{Resumen}

Introducción: La baja de trabajadores por enfermedad representa un grave problema para la industria y la Seguridad Social, porque muchos trabajadores pasan a ser beneficiarios del Instituto Nacional del Seguro Social. Aún no se ha estudiado la relación entre los factores que conducen a baja y el otorgamiento de beneficios a los trabajadores de la industria. Objetivo: Determinar la relación entre factores sociales y ocupacionales en la concesión de prestaciones a trabajadores de la industria con Trastornos Musculo esqueléticos Relacionados con el Trabajo. Métodos: Se trata de un estudio retrospectivo transversal con abordaje cuantitativa, que envolvió a trabajadores industriales. Se utilizaron los datos contenidos en el formulario de evaluación de los trabajadores que fueron admitidos entre 2016 y 2020 en un Centro de Referencia en Salud Ocupacional. Los datos se evaluaron de manera descriptiva y se utilizó regresión logística para estimar los factores que se relacionan con el tipo de asistencia otorgada al trabajador. Resultados: Se evaluaron un total de 108 registros clínicos de trabajadores de la industria, de los cuales el 56,5\% recibió el auxilioenfermedad relacionada con accidentes. La mayoría son trabajadoras $(72,2 \%)$ de la industria con baja demanda $(95,4 \%)$, que realizan trabajo repetitivo $(93,5 \%)$, ritmo de trabajo intenso $(83,3 \%)$, siendo el hombro el segmento más frecuentemente afectado $(85,2 \%)$. Los factores que se relacionaron significativamente con la concesión del auxilioenfermedad relacionada con accidentes: tiempo en la ocupación actual $(\mathrm{OR}=1,01)$, trabajo con flexión de la columna cervical $(\mathrm{OR}=4,68)$, participación en el programa de rehabilitación $(\mathrm{OR}=31,27)$ y consulta con especialistas $(\mathrm{OR}=$ 3,10). Conclusión: Es necesario crear programas institucionales en la industria e implementar políticas de salud pública y seguridad social para controlar dichos factores.

Palabras clave: Enfermedades musculoesqueléticas; Salud laboral; Seguridad social.

\section{Introduction}

The increase in the sickness rates and sick leave by workers without clarifying the causes, added to inefficient rehabilitation, carrying trough an impact on public spending on social security and healthcare (Palheta \& Guimarães, 2017; Goorts, et al., 2018). According to Jay, et al. (2018), the estimated amount of spending on workers away from work in Nordic countries amounts to about $€ 3.36$ billion. Silva, et al. (2011) refer that even in developed countries where there is a greater appreciation and compliance with preventive practices in the workplace, spending on absenteeism permeates $4 \%$ of the Gross Domestic Product (GDP), while these expenditures can reach 10\% of GDP for developing countries (such as Brazil).

Musculoskeletal disorders represent the main causes of decreased work ability of industry workers, comprising one of the main causes of dismissal (Alexopoulos, et al., 2006; Hämmig and Bauer, 2014). Regarding this, Leinonnen, et al. (2018) add that pathologies vary according to the work performed and the type of industry, but that Work-Related Musculoskeletal Disorders (WMSD) are highly prevalent in all occupational classes in this sector.

Industry workers are exposed to a variety of risk factors that can lead to health problems and impaired quality of life (Lowe, et al., 2017). Thus, for Oenning, Carvalho and Lima (2012), an analysis on sick leave should respect the multi-causality of this phenomenon. Factors related to workers' individual aspects should be considered such as the worker's genetics, age, personal habits, hobbies and lifestyle (Virtannen, et al., 2018; Michelleti, et al., 2019); biomechanical factors related to work conditions such as inadequate posture, exposure to the use of physical force, repetitiveness, intense work pace (Cote, et al., 2008); organizational factors related to the type of company, production methods, and periodical medical examinations (Mekonnen, Lamessa \& Wami, 2019); and, finally variables related to physical work conditions - such as cervical flexion 
(Cote, et al., 2008) In addition to the above, Øyeflaten, et al. (2014) confirm that there are factors which predispose sick leave with social security benefits and establish a relationship between returning to the job with participation in professional rehabilitation programs.

Benefits are granted for insured workers of the National Social Security Institute (INSS in Brazil) affected by sickness or accident which temporarily or permanently interferes with their ability to work and receive wages (Brazil, 1991). Social security sickness allowance (B-31) benefit is granted in situations where there is disability for reasons which do not necessarily involve their work activity, and an accident-related sickness allowance (B-91) benefit is granted to workers unable to work as a result of accident or occupational disease. According to Social Security data (Brazil, 2018), over R $\$ 2$ billion (Reais) were spent on granting these two benefits, which together account for more than half of the total benefits granted to formal workers and INSS beneficiaries.

Workers' healthcare in the Brazilian public healthcare system has gained notoriety through the creation of Reference Centers in Occupational Health (CEREST in Brazil) (Brazil, 2009). In this sense, it is the role of CEREST to: identify and attend sick workers, ensure the correct diagnosis through previous and current occupational anamnesis, in addition to clinical and functional assessments, and with that enable (or not) a causal link with work, refer the worker to the INSS, and finally, facilitate access to rehabilitation (Brazil, 2012).

It is necessary to think about strategies for coping with the high number of workers affected by musculoskeletal disorders in need of sick leave which (in specific cases) burden social security. Measures to control musculoskeletal illness in industry workers and the implementation of public policies by CEREST, with the objective of avoiding such events or minimizing the effects of their injuries, depend on an in-depth study on the profile of sick workers and the factors which predispose them to their illness, sick leave and the granting of social benefits. Thus, this study aims to determine the relationship between social and occupational factors to granting sickness benefits to workers in industry affected by WMSD.

This study hypothesizes that the aspects related to current and past socio-occupational information and the work process and sickness of industry workers on sick leave from work due to musculoskeletal illnesses are associated with determining the type of sickness benefit which they will receive.

\section{Methods}

This is a retrospective cross-sectional study implementing a quantitative approach which followed the STROBE guidelines (Von Elm, et al., 2008) for reporting observational studies. Data collection was carried out between March and July 2020 at a Reference Center for Occupational Health (CEREST) in the macro-region of João Pessoa, in the state of Paraíba, Brazil. This CEREST is responsible for assisting workers in conditions of vulnerability to illness or accidents at work in 65 municipalities in Paraiba and organize, together with the other 3 CEREST in the state, the workers' health care network.

This work is in accordance with Resolution 466/12, which regulates research with human beings in Brazil, was approved by the Research Ethics Committee $(C E P)$ of the João Pessoa University Center (UNIPÊ) with CAAE 04401318.2. 0000.5176 , and approved by consolidated opinion no. 3,102,896.

Medical records with completed forms for users aged between 18 and 59 years, of both genders, linked to work in the industry according to the National Registry of Economic Activity (Brazil, 2014) were included to compose the sample. All medical records of industry workers who were admitted to CEREST for having a diagnosis of musculoskeletal illnesses of the spine, shoulder, elbow, wrist and hands were analyzed. These illnesses should form a presumptive link for pathologies classified according to the International Classification of Diseases (ICD) according to Brazil (2003) as Work-Related Musculoskeletal Disorders (WMSD). In addition, they should have been on sick leave from work and have access to a sickness 
benefit granted by the INSS. Medical records of workers who were admitted for being involved in typical occupational accidents in the same segments and workers who were followed up but who did not receive any type of social security benefit were excluded from the survey. The admission period for this study was January 2016 to March 2020, as it refers to the service's active file.

A total of 170 records of workers on sick leave were evaluated. After analyzing the medical records, 14 were excluded for belonging to sick workers who did not return after the first reception and did not complete the evaluation, three medical records were excluded for belonging to workers who suffered a typical work accident or in commuting involving the upper limbs and/or the spine, and 45 others for belonging to workers who filled out the application, but did not receive any type of benefit due to rejection of the request by Social Security.

The Worker's Registration Form in the service was used for data collection, which addresses socio-demographic and socio-occupational issues, occupational and clinical anamnesis, physical examination and therapeutic and administrative procedures (Brasil, 2006). It is noteworthy that all the analyzed forms were filled out when the worker was admitted to the service by the professionals who work at the service, and after training to standardize procedures for approaching and evaluating workers.

The data contained in the form were analyzed using the $\mathrm{R}^{\circledR}$ software program (version 2.14.1). A descriptive analysis was conducted based on absolute and relative frequencies for the variables which comprised the socio-demographic and sociooccupational information, occupational and clinical anamnesis, physical examination and therapeutic and administrative procedures. It is also noteworthy that the averages for continuous variables were calculated and their categorization was determined via the $25^{\text {th }}, 50^{\text {th }}$ and $75^{\text {th }}$ percentiles.

Next, logistic regression was used to identify the variables related to the outcomes (social security sickness grant B31; and accident-related sickness grant - B91). The analysis of these data aimed to highlight characteristics of workers and their work process, as well as their monitoring by CEREST, considering ten groups of research variables. These variables divided by groups and considered likely to be included in the regression are presented in Table 1. The analysis was based on univariate frequency tables and contingency tables between the research variables and the outcome variables.

An estimate was initially made through multiple logistic regression, in which each variable was individually analyzed starting from the contingency tables with the variables which would form the outcome of this study. A significance level of $20 \%$ was considered at this stage, being less judicious than the frequent $5 \%$ used in statistics as it is a screening. Hosmer \& Lemeshow (2000) introduce the idea that variables with a p-value $<0.25$ on the Pearson's Chi-Squared test of the contingency tables become likely candidates for inclusion in logistic regression.

Thus, we used the function deviance (D) in this study to confirm the hypothesis, which is used to measure the discrepancy between the saturated model (best possible model with all variables) and the current model (which includes only the variables included in the final model) to indicate that the model is valid. Next, values were obtained through the contingency tables for the unconditional odds ratios (Odds Ratio), thereby presenting factors which increase or decrease the chance of workers on sick leave to become beneficiaries of one of the types of sickness benefits. The Odds Ratio interpretation of the variables in the final logistic regression model is useful for verifying the effect of each variable on the possibility of the worker on sick leave receiving the B31 (when OR < 1) or B91 (when OR > 1) assistance benefit. A significance level of up to $5 \%$ was considered for the $\mathrm{p}$-value for the final model adjustment. 
Research, Society and Development, v. 10, n. 2, e22610212346, 2021

(CC BY 4.0) | ISSN 2525-3409 | DOI: http://dx.doi.org/10.33448/rsd-v10i2.12346

Table 1 - Variables from the CEREST (Reference Center for Occupational Health) evaluation sheet.

\begin{tabular}{|c|c|c|}
\hline Variable group (quantity) & & Variables \\
\hline \multirow{2}{*}{ Registration data (1) } & \multicolumn{2}{|l|}{ Gender } \\
\hline & \multicolumn{2}{|l|}{ Age } \\
\hline \multirow[t]{16}{*}{ Socio-occupational data (10) } & \multicolumn{2}{|l|}{ Time in occupation } \\
\hline & \multicolumn{2}{|l|}{ Type of contract } \\
\hline & \multicolumn{2}{|l|}{ Time of sick leave } \\
\hline & \multicolumn{2}{|l|}{ Salaried or Not } \\
\hline & \multicolumn{2}{|l|}{ Income declared by the worker } \\
\hline & \multicolumn{2}{|l|}{ Pensioner } \\
\hline & \multicolumn{2}{|l|}{ Number of people living in the house with the worker } \\
\hline & \multirow[t]{3}{*}{ Conducting Occupational Exams } & Admission Exam \\
\hline & & Periodical \\
\hline & & Dismissal \\
\hline & \multirow[t]{5}{*}{ Health services offered by the company to the worker } & $\begin{array}{l}\text { SESMT - Specialized Service in Safety Engineering and Occupational } \\
\text { Medicine }\end{array}$ \\
\hline & & Health insurance \\
\hline & & Physiotherapy \\
\hline & & Psychology \\
\hline & & Nutrition \\
\hline & \multicolumn{2}{|l|}{ Issuance of Workplace Accident Report (WAR) } \\
\hline \multirow[t]{11}{*}{ Biomechanical aspects of work (4) } & \multicolumn{2}{|l|}{ Use of manual tools } \\
\hline & \multicolumn{2}{|l|}{ Repetitive work } \\
\hline & \multirow[t]{9}{*}{ Having to perform difficult physical efforts } & Working in extended sitting posture \\
\hline & & Working in standing posture for a long time \\
\hline & & Activities which require lumbar flexion movements \\
\hline & & Activities which require lumbar rotation movements \\
\hline & & Activities which require cervical flexion movements \\
\hline & & Activities which require cervical rotation movements \\
\hline & & Activities being performed in inappropriate postures \\
\hline & & $\begin{array}{l}\text { Activities which require elevation of the upper limbs (flexion or } \\
\text { abduction) above } 90^{\circ} \text { range of motion }\end{array}$ \\
\hline & & Activities which require shoulder rotation \\
\hline
\end{tabular}


Research, Society and Development, v. 10, n. 2, e22610212346, 2021

(CC BY 4.0) | ISSN 2525-3409 | DOI: http://dx.doi.org/10.33448/rsd-v10i2.12346

\begin{tabular}{|c|c|c|}
\hline & \multirow{7}{*}{ Lifting weight } & Activities which require circular movements of the wrists \\
\hline & & Application of sudden forces to the upper limb muscles \\
\hline & & Squatting \\
\hline & & Application of sudden forces to the lower limb muscles \\
\hline & & Need to go up and down stairs \\
\hline & & Lifting frequency \\
\hline & & Weight of lifted material \\
\hline \multirow[t]{8}{*}{ Organizational aspects of work $(8)$} & \multicolumn{2}{|l|}{ Breaks included in the work process } \\
\hline & \multicolumn{2}{|l|}{ Job satisfaction } \\
\hline & \multicolumn{2}{|l|}{ Previous training } \\
\hline & \multirow{2}{*}{\multicolumn{2}{|c|}{$\begin{array}{l}\text { Intense work pace } \\
\text { Number of hours worked per day }\end{array}$}} \\
\hline & & \\
\hline & Number of days worked per week & \\
\hline & \multicolumn{2}{|l|}{ Meal provided in the company } \\
\hline & Overtime performed & Number of overtime hours worked per week \\
\hline \multirow[t]{7}{*}{ Work safety aspects (4) } & \multirow[t]{4}{*}{ Exposure to environmental risks at work } & Physical Risks \\
\hline & & Chemical \\
\hline & & Biological \\
\hline & & Mechanical \\
\hline & \multicolumn{2}{|l|}{ Use of Personal Protective Equipment (PPE) } \\
\hline & \multicolumn{2}{|l|}{ Lack of job security } \\
\hline & \multicolumn{2}{|l|}{ Implementation of security actions by the company } \\
\hline \multirow[t]{6}{*}{ Previous occupational history (3) } & \multicolumn{2}{|l|}{ Child labor history } \\
\hline & \multicolumn{2}{|l|}{ Formal work prior to last or current job } \\
\hline & \multirow[t]{4}{*}{ Exposure to environmental risks in previous work } & Physical Risks \\
\hline & & Chemical \\
\hline & & Biological \\
\hline & & Mechanical \\
\hline \multirow[t]{5}{*}{ Affected region/segment (5) } & \multicolumn{2}{|l|}{ Lumbar spine } \\
\hline & \multicolumn{2}{|l|}{ Cervical spine } \\
\hline & \multicolumn{2}{|l|}{ Shoulder } \\
\hline & \multicolumn{2}{|l|}{ Elbow } \\
\hline & \multicolumn{2}{|l|}{ Wrist/Hand } \\
\hline \multirow[t]{3}{*}{ History of disease and benefits (10) } & \multicolumn{2}{|l|}{ Symptom onset time } \\
\hline & \multicolumn{2}{|c|}{ Change of function in the current company due to sickness } \\
\hline & Leave of less than 15 days with medical certificates & How many days on leave \\
\hline
\end{tabular}


Research, Society and Development, v. 10, n. 2, e22610212346, 2021

(CC BY 4.0) | ISSN 2525-3409 | DOI: http://dx.doi.org/10.33448/rsd-v10i2.12346

\begin{tabular}{|c|c|c|}
\hline & Leave with benefits greater than 15 days & Number of months on leave with sickness benefit \\
\hline & & Number of months on leave with accidental sickness benefit \\
\hline & Diagnosis completed by exams & \\
\hline & Performing surgery because of sickness & \\
\hline & Conducting physical therapy treatment be & ess \\
\hline & Participation in INSS (national social sect & professional rehabilitation programs \\
\hline & Presentation of expert report & \\
\hline & Diseases presented by parents with the po & edity. \\
\hline Technical conducts (10) & Indication for continued leave & \\
\hline & Prescription or guidance on the use of me & \\
\hline & Referral to physiotherapy & \\
\hline & Indication for surgery & \\
\hline & Establishment of nexus & \\
\hline & Compulsory disease notification & \\
\hline & Issuance of documents & Medical certificate \\
\hline & & Report to the company \\
\hline & & Report to the union \\
\hline & & Workplace Accident Report (WAR) \\
\hline & & Issuance of declaration \\
\hline & & Issuance of Reports \\
\hline & Labor and/or social security guidelines & \\
\hline & Examination request & \\
\hline & Indication for professional rehabilitation & \\
\hline Administrative conducts (6) & Referral to the INSS & \\
\hline & Worker return for control & \\
\hline & Return of the worker for investigation of & \\
\hline & Referrals to expert consultations & \\
\hline & Discharge with referral to other health ser & \\
\hline & CEREST discharge & \\
\hline
\end{tabular}

Source: Research Data (2020). 


\section{Results}

The final sample consisted of 108 medical records of industry workers with a diagnosis of musculoskeletal disorders who were on sick leave from work and had access to a benefit typified as social security or accident-related sickness benefit granted by the INSS, as specified in the inclusion criteria.

Table 2 shows the sample distribution regarding its characterization in relation to the variables extracted from the medical records.

Table 2 - General characterization of the sample.

\begin{tabular}{|c|c|c|}
\hline Characteristic & $\mathbf{N}$ & $\%$ \\
\hline \multicolumn{3}{|l|}{ Type of industry } \\
\hline Light Industry & 103 & 95.4 \\
\hline Heavy Industry & 5 & 4.6 \\
\hline \multicolumn{3}{|l|}{ Gender } \\
\hline Male & 30 & 27.8 \\
\hline Female & 78 & 72.2 \\
\hline \multicolumn{3}{|l|}{ Age } \\
\hline 18 to 28 years & 10 & 9.2 \\
\hline 29 to 38 years & 47 & 43.5 \\
\hline 39 to 48 years & 45 & 41.6 \\
\hline 49 to 58 years & 6 & 5.5 \\
\hline \multicolumn{3}{|l|}{ Time in occupation } \\
\hline Up to 43 months & 27 & 25 \\
\hline 44 to 96 months & 38 & 35.2 \\
\hline 97 to 141 months & 16 & 14.8 \\
\hline More than 142 months & 27 & 25 \\
\hline \multicolumn{3}{|l|}{ Employment situation } \\
\hline Employed & 95 & 88 \\
\hline Unemployed & 13 & 12 \\
\hline \multicolumn{3}{|l|}{ Time of leave } \\
\hline Up to 15 days & 34 & 31.5 \\
\hline From 16 days up to 2 months & 22 & 20.4 \\
\hline From 3 months to 12 months & 25 & 23.1 \\
\hline More than 13 months & 27 & 25 \\
\hline \multicolumn{3}{|l|}{ Formalization } \\
\hline Yes & 95 & 88 \\
\hline No & 13 & 12 \\
\hline \multicolumn{3}{|l|}{ Income } \\
\hline No income & 6 & 5.6 \\
\hline Have income & 102 & 94.4 \\
\hline \multicolumn{3}{|l|}{ Type of benefit granted } \\
\hline Social security sickness benefit (B-31) & 47 & 43.5 \\
\hline Accident-related sickness pay (B-91) & 61 & 56.5 \\
\hline \multicolumn{3}{|l|}{ Currently receiving the benefit } \\
\hline Yes & 57 & 52.8 \\
\hline
\end{tabular}


No

Number of people living in the home

Live alone

2 people

3 people

42.6

More than 4 people

Exams

Admission Exam

99.1

Periodical

107

88

Dismissal

16.6

Healthcare in the company

Healthcare services

98.1

SESMT

Healthcare plan

WAR issued

Yes

No

Use of manual tools

Yes

No

Repetitive work

Yes

No

Rest breaks during work

Yes

No

Intense work pace

Yes

No

Difficult physical efforts

Yes

No

Type of physical efforts

Sitting work

Standing work

Lumbar flexion

Lumbar rotation

Cervical flexion

Cervical rotation

Inadequate postures

Elevated UL with shoulder ROM greater than $90^{\circ}$

Shoulder rotation

Circular wrist movements

Abrupt forces with UL

Squatting 
Stairs

Lifting weight

Work satisfaction

Yes

No

Previous training for the job

Yes

No

Work days/week

5 days/week

6 days/week

Overtime

Yes

No

Amount of overtime/week

None

Up to $2 \mathrm{~h} /$ week

More than $2 \mathrm{~h} /$ week

Presence of environmental risks

Physical

Chemical 55.5

Biological

Accidents

PPE use

Yes

No

Lack of work safety

Yes

No

Safety actions

Yes

No

Meal provided

Yes

No

Child labor

Yes

No

Worked before

Yes

Environmental risks in previous jobs

Physical

Chemical

Biological 


\section{Onset of symptoms}

Up to 24 months 29.6

From 25 to 48 months

From 49 to 72 months

More than 73 months

Change in function due to sickness

Yes

No

Diagnosis

Yes

Sickness absence with medical certificate issued by the company

Yes

No

Months on leave with B31

From 1 to 3 months

More than 4 months

Months on leave with B91

Up to 6 months

From 7 to 12 months

From 13 to 24 months

From 25 to 36 months

More than 37 months

History of surgery in the affected region

Yes

No

History of physical therapy intervention

Yes

No

Professional rehabilitation of the INSS (National Social Security

No

Forensic report

Yes

No

Genetic illness/disease

Yes

No

Affected region

Shoulder

Elbow

Wrist

Cervical

Lower back

Technical conducts 


\begin{tabular}{lrr} 
Leave & 53 & 49.1 \\
Medication & 61 & 56.5 \\
Physiotherapy Monitoring & 52 & 48.2 \\
Surgery & 3 & 2.8 \\
Nexus & 67 & 62 \\
Medical certificate & 3 & 2.8 \\
$D R T$ notification & 2 & 1.9 \\
Report to the company & 2 & 1.9 \\
Union notification & 2 & 1.9 \\
VISAT notification & 22 & 20.4 \\
WAR issue & 86 & 79.6 \\
Referral to professional rehabilitation & 1 & 0.9 \\
Labor/social security guidance & 8 & 7.4 \\
Declaration & 2 & 1.9 \\
Issuance of reports & 1 & 0.9 \\
Request exams & 1 & 0.9 \\
Administrative conducts & & \\
Referral to INSS & 8 & 7.4 \\
Return for control & 12 \\
Return for investigation/clarification & 2 & 1.9 \\
Referral to expert consultation & 13 & 12 \\
Discharge with referral to other services & 49 & 45.4 \\
CEREST discharge & 6 & 5.6 \\
\hline
\end{tabular}

Legend: SESMT - Specialized Safety and Occupational Medicine Service; UL - Upper Limb; ROM - Range of Movement; LL - Lower Limbs; PPE - Personal Protective Equipment; B31 - Social Security sickness benefit or Type 31 Benefit; B91 - Accident sickness benefit or benefit type 91; INSS - National Social Security Institute; DRT - Regional Labor Office; VISAT - Occupational Health Surveillance; WAR Workplace Accident Report; CEREST - Reference Center for Occupational Health.

Source: Research Data (2020).

Table 3 presents the factors which determine granting each of the benefits. As evidenced, the variables which showed a significant association ( $\mathrm{p}<0.05$ ) with granting the accident-related sickness assistance benefit (B-91) were: time in occupation current, work with cervical flexion requirement, participation in the INSS professional rehabilitation program, and referral for consultations with medical specialists; in addition, the variables with no significant association and with an effect for the social security sickness assistance benefit (B-31) were the performance of dismissal exam and previous work with exposure to chemical risk.

This table also shows the $\beta$ values which is the regression coefficient, and represents the numerical slope for the type of sickness benefit to be granted in the case of sick leave in the final regression model. 
Table 3 - Factors associated with the type of sickness benefit to be granted.

\begin{tabular}{cccc}
\hline Variable & $\boldsymbol{\beta}$ & Type of benefit & $\boldsymbol{p}$-value \\
\hline $\begin{array}{c}\text { Intercept } \\
\text { Current occupation time }\end{array}$ & -1.28 & - & $0.014^{*}$ \\
$\quad 0.01$ & B91 & $0.004^{*}$ \\
$\begin{array}{c}\text { Conducting a dismissal exam } \\
\text { Working with Cervical Spine Flexion }\end{array}$ & -1.00 & B31 & $0.036^{*}$ \\
$\begin{array}{c}\text { Previous Work with Exposure to } \\
\quad \text { Chemical Risk }\end{array}$ & 1.55 & B91 & $0.015^{*}$ \\
$\begin{array}{c}\text { INSS Professional Rehabilitation } \\
\quad\end{array}$ & 3.44 & B31 & $0.007^{*}$ \\
$\begin{array}{c}\text { Referral for consultation with } \\
\text { specialists }\end{array}$ & 1.13 & B91 & $* *$ \\
\hline
\end{tabular}

Note: $* p$-value $<0.05 ; * * p$-value $<0.01$

Legend: INSS - National Social Security Institute

Source: Research Data (2020).

The Odds Ratio results for the variables which influence the final model are shown in Table 4, and as evidenced in the case of sick leave from work due to WMSD, the industrial worker was more likely to receive the B91 when participating in the INSS rehabilitation program $(\mathrm{OR}=31.27 ; 95 \% \mathrm{CI}=4.92-19.71)$, when performing a function that requires cervical spine flexion $(\mathrm{OR}=4.68 ; 95 \% \mathrm{CI}=1.25-16.29)$, when attending consultations with specialists $(\mathrm{OR}=3.10 ; 95 \% \mathrm{CI}=1.12-8.56)$, and those who have spent considerable time doing the same function $(\mathrm{OR}=1.01 ; 95 \% \mathrm{CI}=1.00-1.01)$. Conversely, the chances of B31 being granted are increased when the worker performs a dismissal exam $(\mathrm{OR}=0.22 ; 95 \% \mathrm{CI}=0.05-0.91)$ and when they are exposed to chemical risk in a previous job $(\mathrm{OR}=0.21 ; 95 \% \mathrm{CI}=0.06-0.66)$.

It is also noteworthy that the model of our study presents results according to the deviance function (D) which confirm the hypothesis, since the D statistic related to the logistic regression model (97.90) was less than the Chi-squared reference value (125.45) with 101 degrees of freedom.

Table 4 - Predictors of logistic regression for the type of sickness benefit assistance granted.

\begin{tabular}{clc}
\hline Predictors & Odds ratio (95\% CI) & Effect \\
\hline Current occupation time & $1.01(1.003-1.019)$ & B91 \\
Conducting a dismissal exam & $0.22(0.056-0.913)$ & B31 \\
Working with Cervical Spine Flexion & $4.68(1.258-16.292)$ & B91 \\
Previous Work with Exposure to Chemical Risk & $0.21(0.069-0.665)$ & B91 \\
INSS Professional Rehabilitation & $31.27(4.923-19.717)$ & B91 \\
Referral for consultation with specialists & $3.10(1.125-8.564)$ & \\
\hline
\end{tabular}

Legend: INSS - National Social Security Institute; 95\% CI - 95\% Confidence Interval.

Source: Research Data (2020). 


\section{Discussion}

The results evidenced that the time in the current occupation, performing actions with frequent demand for cervical flexion, participation in the INSS professional rehabilitation program and investigating the diagnosis through consultations with several specialists may be factors which explain granting the accident-related sickness benefit (B91), which is only granted in social security when the causal link of work is established as a conditioning factor for the illness. The factors related to granting the social security sickness benefit (B31) without establishing a link were performance of a dismissal exam and previous work with exposure to chemical risk.

Regarding the relationship between the predictive factors for the type of benefit, it was found that time in the occupation is a factor which tends to explain the illness as being related to work. A similar result was found in the automobile industry (Zhou, et al., 2018); however, the time in our study became significant after 43 months in the same function. Coury, et al. (2002) found that periods of more than 7 months in a function can influence the appearance of musculoskeletal symptoms. Exposure time is considered a primary risk for these diseases (Putz-Anderson, 2017), as the time working in the same company or function is related to accumulated exposure to the risks that it imposes, in turn being reflected in illness (Viegas \& Almeida, 2016), which Negri, et al. (2014) calls "activity-dependent" pathologies.

The variable of conducting a dismissal exam explained granting the B-31 benefit (social security sickness benefit). The fact that a portion of the workers who were receiving this benefit had been dismissed from employment when they entered the benefit expresses the vulnerability of the sick worker to be dismissed, since this type of assistance does not provide legal stability for returning to work after going on sick leave. Pestana, et al. (2017) found that fear of dismissal is common in sick leave workers who have to return to work. This feeling acts as a catalyst for the worker to neglect their own physical limitations imposed by their health condition, and seek to produce even more, placing them in a vicious cycle of greater exposure to the harmful mechanism and worsening the pathology, which consequently causes a need for new periods of absence.

A possible explanation regarding the B31 benefit granted being influenced by the fact that the worker has already worked in workplaces exposed to chemical risks is that exposure to different types of risk throughout their professional career can make it difficult to establish the main cause of illness, preventing granting the benefit which establishes the causal link of the disease (B91). Chemical risks in the case of musculoskeletal illness could be treated as a concausal link through the "theory of equivalence of conditions" proposed by the Brazilian Social Security evaluation system (Brazil, 1991). The presence of chemical risk does not prevent the musculoskeletal pathology from being related to work, but the lack of evidence or research to prove exposure to these risks in previous works may constitute factors which explain the refusal to grant the social security sickness benefit by social security.

The work performed requiring cervical spine flexion was one of the factors which explains recognizing the diseasework relationship and granting the B91 benefit. Cervical flexion has been identified as one of the main biomechanical risk factors in the work process for developing musculoskeletal disorders in the upper and cervical limbs (Palmer \& Smedley, 2007; Park, et al., 2010; Zebis, et al., 2011). These were also the regions most frequently affected in our study, as evidenced by injuries to the shoulder (85.2\%), wrists/hands (24.1\%) and cervical spine (13.9\%). Nourollahi-Darabad, et al. (2018) refer that cervical flexion predisposes a worker even more to WMSD when they are involved in repetitive or monotonous tasks and intense work pace; a situation which was also described as having high frequency by the workers in our study. These issues can provide the necessary security for the social security benefit to be granted. However, Oliveira \& Oliveira (2020) suggest that ergonomic measures can be easily implemented to redesign the physical work environment in the industry. 
Participation in the INSS rehabilitation program proved to be a favorable factor in granting social security sickness benefits. Inclusion in this type of program is a resource applied to workers who have an indication for long-term leave. Takahashi, et al. (2010) refer that this is the main strategy of the Brazilian social security system to cope with work incapacity, being fundamental in reducing the duration of the benefit provided to sick workers and positioning them in new roles which respect their limitations. Therefore, workers who have more severe disabilities, who need more time away from work and who have greater difficulty in performing their work function are those who go through the INSS program, and are therefore more prone to social security sickness benefits.

As this study analyzed granting benefits to workers on leave due to musculoskeletal disorders, the relationship between professional rehabilitation and granting benefits is explained by the ideas of Gjesdal \& Bratberg (2003), Brage, et al. (2010) and Gabbay, et al. (2011), who refer that granting long-term benefits due to severe labor incapacity in most countries of the world refer to musculoskeletal system diseases, and therefore workers affected by such diseases become the most frequently indicated for programs professional rehabilitation.

Finally, it was found that workers who were referred by CEREST professionals for consultations with specialists from different health areas were 3.1 times more likely to receive the B91 benefit. This relationship can be explained by the need for long-term benefits to only be granted to workers who have undergone a continuous and integrated assessment, allowing for a safe and fair decision to verify work incapacity arising from illness due to work (Miranda, 2018).

Consultation with other professionals and specialists is an important element in diagnosing WMSD. Øyeflaten, et al. (2014) state that recognizing the disease as work-related should be the result of a thorough process and considers the multifactorial nature of these changes. Nilsen, et al. (2011) and Maeland, et al. (2012) refer that the diagnosis - by itself cannot be considered as a factor for granting benefits, and (according to these authors) the validity of this diagnosis should be periodically questioned by specialized professionals, especially for the more complex cases involving patients with subjective health complaints such as pain and limited functions.

\subsection{Study limitations and perspectives}

The fact that this study is based on data from a single worker assistance service stands out as a limitation of this study, because even though it is still a reference institution in providing care for this specific group of patients, it has a loco-regional reality and its results should be interpreted with caution. We also consider the small sample size as a limitation, which can be explained by the fact that the medical records which composed the current file of the Reference Center for Occupational Health were used.

Based on this, it is believed that future studies may focus on evaluating data from other services that sick workers go through such as diagnostic and rehabilitation centers, social security institutes or even data collected in the industry itself, such as those contained in medical records or even direct assessment processes with workers.

The results presented here can be used to direct collective health and work safety actions through creating measures which seek to eliminate the factors that were favorable to the workers going on leave and the benefits being granted. Even so, they can assist in the decision-making process for establishing the causal link for work-related musculoskeletal disorders both by CEREST and INSS professionals. There is also the possibility that the data presented herein can be used as a scientific basis to develop and adopt preventive and control measures regarding this group of diseases with workers in the industry.

It is further worth noting the need to expand the offer of professional rehabilitation services along the INSS lines, and access to diagnostic methods which bring early information about possible workers' commitments through periodic examinations during their working time in the industry. It is also recommended to implement methods of assessing personal 
Research, Society and Development, v. 10, n. 2, e22610212346, 2021

(CC BY 4.0) | ISSN 2525-3409 | DOI: http://dx.doi.org/10.33448/rsd-v10i2.12346

and biomechanical factors in the industries' work environments in order to implement effective interventions, such as rotating organizational tasks and/or institutional programs for periodic job changes, aimed at remedying short- and long-term effects of exposure to risks such as prolonged cervical flexion posture.

\section{Conclusion}

This study presented an analysis of the factors related to granting different types of benefits by industrial workers. The time in the current occupation, work involving cervical spine flexion, participation in the INSS rehabilitation program and referral to consultations with specialists are factors related to granting accident-related sickness benefit (B91) and performing the dismissal exam and previous work with exposure to chemical risk are related to granting the social security sickness benefit (B31). Controlling these risk factors by implementing organizational changes and intervention programs can contribute to reducing the prevalence of sick leave due to musculoskeletal disorders and social security expenses in this population.

\section{Acknowledgments}

The authors are grateful to CAPES - Brazilian Federal Agency for Support and Evaluation of Graduate Education within the Ministry of Education of Brazil - Financing Code 001.

\section{References}

Alexopoulos, E. C., Tanagra, D., Konstantinou, E., \& Burdorf, A. (2006). Musculoskeletal disorders in shipyard industry: prevalence, health care use, and absenteeism. BMC musculoskeletal disorders, 7(1), 1-10.

Brage, S. et al. (2010) Musculoskeletal disorders as causes of sick leave and disability benefits. Norwegian Medical Association Journal: Journal of Practical Medicine, 130 (23): 2369-2370.

Brasil (2006) Ministério da Saúde. Manual de gestão e gerenciamento: Rede Nacional de Atenção Integral à Saúde do Trabalhador. Brasília.

Côté, P. et al. (2008) The burden and determinants of neck pain in workers. European Spine Journal, (17) 1, 60-74.

Coury, H. J. C. G., Porcatti, I. A., Alem, M. E., \& Oishi, J. (2002). Influence of gender on work-related musculoskeletal disorders in repetitive tasks. International journal of industrial ergonomics, 29(1), 33-39.

Gabbay, M., Taylor, L., Sheppard, L., Hillage, J., Bambra, C., Ford, F., \& Kelly, M. P. (2011). NICE guidance on long-term sickness and incapacity. British Journal of General Practice, 61(584), e118-e124.

Gjesdal, S., \& Bratberg, E. (2003). Diagnosis and duration of sickness absence as predictors for disability pension: results from a three-year, multi-register based* and prospective study. Scandinavian journal of public health, 31(4), 246-254.

Goorts, K., Vandenbroeck, S., Rusu, D., Du Bois, M., \& Godderis, L. (2018). Screening for the risk on long-term sickness absence. Journal of public health research, 7(2).

Hämmig, O., \& Bauer, G. F. (2014). Work, work-life conflict and health in an industrial work environment. Occupational Medicine, 64(1), 34-38.

Hosmer, D. W., \& Lemeshow, S. (2000). Applied Logistic Regression. John Wiley \& Sons.

Instituto Nacional de Seguridade Social - INSS. Secretaria de Políticas de Previdência Social. Coordenação-Geral de Estatística, Demografia e Atuária. Boletim Estatístico Da Previdência Social. Brasília.

Jay, K., Thorsen, S. V., Sundstrup, E., Aiguadé, R., Casaña, J., Calatayud, J., \& Andersen, L. L. (2018). Fear avoidance beliefs and risk of long-term sickness absence: prospective cohort study among workers with musculoskeletal pain. Pain research and treatment, 2018.

Lei nº 8.213, 24 de julho de 1991. Dispõe sobre os Planos de Benefícios da Previdência Social e dá outras providências. Diário Oficial da União. Brasília.

Leinonen, T., Viikari-Juntura, E., Husgafvel-Pursiainen, K., \& Solovieva, S. (2018). Cause-specific sickness absence trends by occupational class and industrial sector in the context of recent labour market changes: a Finnish panel data study. BMJ open, 8(4).

Lowe, B. D., Shaw, P. B., Wilson, S. R., Whitaker, J. R., Witherspoon, G. J., Hudock, S. D., \& Wurzelbacher, S. J. (2017). Evaluation of a workplace exercise program for control of shoulder disorders in overhead assembly work. Journal of occupational and environmental medicine, $59(6), 563$.

Maeland, S., Werner, E. L., Rosendal, M., Jonsdottir, I. H., Magnussen, L. H., Ursin, H., \& Eriksen, H. R. (2012). Diagnoses of patients with severe subjective health complaints in Scandinavia: a cross sectional study. International Scholarly Research Notices, 47(4), 311-318. 
Research, Society and Development, v. 10, n. 2, e22610212346, 2021

(CC BY 4.0) | ISSN 2525-3409 | DOI: http://dx.doi.org/10.33448/rsd-v10i2.12346

Mekonnen, T. H., Lamessa, S. K., \& Wami, S. D. (2019). Sickness-related absenteeism and risk factors associated among flower farm industry workers in Bishoftu town, Southeast Ethiopia, 2018: a cross-sectional study. BMC research notes, 12(1), 181.

Micheletti, J. K., Bláfoss, R., Sundstrup, E., Bay, H., Pastre, C. M., \& Andersen, L. L. (2019). Association between lifestyle and musculoskeletal pain: crosssectional study among 10,000 adults from the general working population. BMC musculoskeletal disorders, 20(1), 1-8.

Ministério da Economia. Receita Federal do Brasil. Classificação Nacional de Atividades Econômicas (CNAE). Brasília.

Ministério da Previdência Social. Instrução Normativa $\mathrm{n}^{\circ}$ 98, de 5 de dezembro de 2003. Aprova Norma Técnica sobre Lesões por Esforços Repetitivos - LER ou Distúrbios Osteomusculares Relacionados ao Trabalho - DORT. Diário Oficial da União. Brasília.

Ministério da Saúde. Portaria n ${ }^{\circ}$ 2.728, de 11 de novembro de 2009. Dispõe sobre a Rede Nacional de Atenção Integral à Saúde do Trabalhador (RENAST) e dá outras providências. Diário Oficial da União. Brasília.

Ministério da Saúde. Secretaria de Vigilância em Saúde. Departamento de Vigilância em Saúde Ambiental e Saúde do Trabalhador. Dor relacionada ao trabalho: lesões por esforços repetitivos (LER): distúrbios osteomusculares relacionados ao Trabalho (DORT). Brasília: Editora do Ministério da Saúde.

Miranda, C. B. (2008) Aspectos do cenário atual da reabilitação profissional no Brasil: avanços e retrocessos. Cadernos de Saúde Pública, 34 : 218717.

Negri, J. R., Cerveny, G. C. O., Montebelo, M. I. L., \& Teodori, R. M. (2015) Perfil sociodemográfico e ocupacional de trabalhadores com LER/DORT: estudo epidemiológico. Revista Baiana de Saúde Pública, 38(3): 555-570.

Nilsen, S., Werner, E. L., Maeland, S., Eriksen, H. R., \& Magnussen, L. H. (2011). Considerations made by the general practitioner when dealing with sicklisting of patients suffering from subjective and composite health complaints. Scandinavian journal of primary health care, 29(1), 7-12.

Nourollahi-Darabad, M. N., Mazloumi, A., Saraji, G.N., Afshari D. \& Foroushani. A. R. (2018) Full shift assessment of back and head postures in overhead crane operators with and without symptoms. Journal of occupational health, 60: 46-54.

Oenning, N. S. X., Carvalho, F. M., \& Lima, V. M. C. (2014). Risk factors for absenteeism due to sick leave in the petroleum industry. Revista de saude publica, 48, 103-122.

Oliveira, M. T. O., \& Oliveira, A. P. (2020). A ergonomia na indústria da cerâmica: Uma avaliação ergonômica em trabalhadores. Research, Society and Development, 9(12), e25291210971.

Øyeflaten, I., Lie, S. A., Ihlebæk, C. M., \& Eriksen, H. R. (2014). Prognostic factors for return to work, sickness benefits, and transitions between these states: a 4-year follow-up after work-related rehabilitation. Journal of occupational rehabilitation, 24(2), 199-212.

Palheta, C. F., \& Guimarães, M. G. V. (2017) Absenteísmo por motivo de doença: um estudo em uma indústria do polo industrial de Manaus. Qualitas Revista Eletrônica, 18 (1): 01-17.

Palmer, K. T., \& Smedley, J. (2007). Work relatedness of chronic neck pain with physical findings-a systematic review. Scandinavian journal of work, environment \& health, 165-191.

Park, B. C., Cheong, H. K., Kim, E. A., \& Kim, S. G. (2010). Risk factors of work-related upper extremity musculoskeletal disorders in male shipyard workers: structural equation model analysis. Safety and health at work, 1(2), 124-133.

Pestana, B. M., Valença, J.M, Graeser, A. E. M, \& Alencar, M. C. B. (2017) The return to work of individuals with musculoskeletal disorders. Cadernos Brasileiros de Terapia Ocupacional, 25 (4), 735-742.

Putz-Anderson, V. (Ed.). (2017). Cumulative trauma disorders. CRC Press.

Silva, L. R., Galvan, L., Sakae, T. M., \& Magajewski, F. R. L. (2011) Nexo técnico epidemiológico previdenciário: perfil dos benefícios previdenciários e acidentários concedidos pelo INSS na região do Vale do Itajaí (SC) antes e depois da norma. Rev Bras Med Trab, 9(2): 69-77.

Takahashi, M. A. B. C., Simonelli, A.P., Sousa, H. P., Mendes, R. W. B., \& Alvarenga, M. V. A. (2010) Programa de reabilitação profissional para trabalhadores com incapacidades por LER/DORT: relato de experiência do CEREST-Piracicaba, SP. Revista Brasileira de Saúde Ocupacional, 35 (121): 100111.

Viegas, L. R. T., \& Almeida, M. M. C. (2016) Perfil epidemiológico dos casos de LER/DORT entre trabalhadores da indústria no Brasil no período de 2007 a 2013. Revista Brasileira de Saúde Ocupacional, 41.

Virtanen, M., Ervasti, J., Head, J., Oksanen, T., Salo, P., Pentti, J., \& Kivimäki, M. (2018). Lifestyle factors and risk of sickness absence from work: a multicohort study. The Lancet Public Health, 3(11), e545-e554.

von Elm E., Altman D. G., Egger M., Pocock S. J., Gøtzsche P. C., Vandenbroucke J. P., \& STROBE Initiative. (2008) Strengthening the Reporting of Observational Studies in Epidemiology (STROBE) statement: guidelines for reporting observational studies. J Clin Epidemiol., 61(4): $344-349$.

Zebis, M. K., Andersen, L. L., Pedersen, M. T., Mortensen, P., Andersen, C. H., Pedersen, M. M., \& Sjøgaard, G. (2011). Implementation of neck/shoulder exercises for pain relief among industrial workers: a randomized controlled trial. BMC musculoskeletal disorders, 12(1), 1-9.

Zhou Y. C., Zheng H. Y., Liu H. Z., Pan W. N., Feng J. Q., Liu X. X. (2018) The correlation of Occupational musculoskeletal disorders and occupational safety behaviors in assembly line workers. Chinese journal of industrial hygiene and occupational diseases, 36(7):516-519. 